\title{
Subverting Reality: The Role of Propaganda in 21st Century Intelligence
}

\section{Chad W. Fitzgerald \& Aaron F. Brantly}

To cite this article: Chad W. Fitzgerald \& Aaron F. Brantly (2017) Subverting Reality: The Role of Propaganda in 21st Century Intelligence, International Journal of Intelligence and Counterlntelligence, 30:2, 215-240, DOI: 10.1080/08850607.2017.1263528

To link to this article: http://dx.doi.org/10.1080/08850607.2017.1263528

曲 Published online: 08 Feb 2017.

Submit your article to this journal $\pi$

Џlll Article views: 187

Q View related articles ¿

View Crossmark data ¿ 


\section{CHAD W. FITZGERALD and AARON F. BRANTLY Subverting Reality: The Role of Propaganda in 21 st Century Intelligence}

The digital era has placed most of humanity's knowledge within a few clicks of a computer mouse or the touches of a smart phone screen. Yet in an age where knowledge is so readily available it is also seemingly elusive. Reality hides behind oceans of information streamed from innumerable sources competing for a single moment of attention. But disinformation dangerously poisons that abundance of knowledge and begins a process of ideational inception, in which even the idea of reality is itself subverted.

In the digital age, propaganda and disinformation injected into the global information environment, known now as cyberspace, can have significant

Major Chad W. Fitzgerald of the United States Army is Assistant Professor of International Relations in the Department of Social Sciences at the United States Military Academy, West Point, New York. A graduate in History from Texas Christian University, he received his M.A. in International Relations from the Fletcher School of Law and Diplomacy at Tufts University, Medford, Massachusetts. Major Fitzgerald, an active duty field artillery officer with more than a dozen years' service, is the veteran of multiple deployments to Iraq and Europe.

Aaron F. Brantly is Assistant Professor of International Relations and Cyber in the Department of Social Sciences and the Department of Electrical Engineering and Computer Science, Cyber Policy Fellow at the Army Cyber Institute and Cyber Fellow at the Combating Terrorism Center. He holds a Ph.D. in Political Science from the University of Georgia and a Master's of Public Policy from American University. His newly published book The Decision to Attack: Military and Intelligence Cyber Decision-making was published through the University of Georgia Press. 
implications. Strategically utilized in the digital era, they can facilitate significant political actions that slow or dilute policy responses. They also pose a direct and relevant threat to national security, both within target nations as well as in those beyond the intended scope of a given operation.

The number of information sources available to the average consumer has increased exponentially over the past 60 years. Whereas in the $1950 \mathrm{~s}$ an individual might have had access to abundant radio programming, a few television channels, and dozens of newspapers and weekly magazines, today that same individual has access not only to hundreds of radio and television channels, but to almost every newspaper or magazine, whether print or digital, on the planet. Whereas in the 1980s or 1990s people needed to go to the library or a bookstore to access a book, they now have access to nearly all books in all languages through the phone in their pocket. ${ }^{1}$ As recently as 2005, if an earthquake hit along the San Andreas Fault there might not be enough time for a warning to reach Los Angeles; now, with Twitter, news of the quake can reach around the globe before the surface of a cup of coffee ripples in Malibu. ${ }^{2}$ Nearly 3 billion individuals are connected to the Internet globally, comprising approximately 40 percent of the world's population. ${ }^{3}$ That number is expected to increase in the coming years. But the ever-pervasive WiFi and mobile networks are now targets of information operations, both friendly and unfriendly. Even in places like Cuba where the Internet has not yet made significant inroads, citizens are able to spread digital media by the gigabyte on CDs, DVDs, and USBs. ${ }^{4}$ The days of Western intelligence services sending a few thousand videos and books across the border into the Soviet Union have been overtaken by an information environment in which information boundaries have been, if not lost, substantially minimized. Natalya Sverjensky refers to this era of pervasive information as an age of information overload. ${ }^{5}$

The digital information environment poses problems for conventional practitioners of propaganda. The diffusion of the information environment has made it more difficult to capture the opinions of a target population through individually well-placed articles or news stories on radio, television, or in print publications of importance. Targeting the linear flow of information outward by placing propaganda in potential source sites in non-target countries in the hopes they will be picked up and re-broadcast or printed has also become increasingly difficult. The difficulty is not due the contents of a piece of propaganda, but rather to its being subsumed in a cacophony of competing information sources. As a result, propaganda strategy has become multi-vectored to achieve a diffusion across all potential points of access. Moreover, in most instances the information environment is no longer containable geographically as information 
diffusion through disparate networks is rapid. This enhanced connectedness increases the potential for blowback against domestic populations. ${ }^{6}$

\section{FROM THE USSR WITH LOVE}

The focus here is on the evolution of the information operations of the Soviet Union Komitet Gosudarstvennoy Gezopasnosti (KGB - Committee for State Security) as they have transitioned from the Cold War era into the post-Cold War Russian Federation's Sluzhba Vneshney Razvedki (SVR) and Glavnoye Razvedyvatel'noe Upravleniye (GRU—Main Intelligence Directorate of the General Staff of the Armed forces of the Russian Federation). The study follows a timeline covering three primary operational environments over the course of 40 years.

Legal and regulatory requirements, as well as moral and ethical constraints, differ from country to country. The three cases presented here largely represent strategic information operations by an unconstrained state service and are therefore illustrative of generalized behaviors possible under propaganda and disinformation.

\section{A BRIEF OVERVIEW OF PROPAGANDA AND DISINFORMATION}

During a conflict, participating nations typically resort to some sort of propaganda both domestically and internationally. The time horizon can influence the typology of propaganda or disinformation being used. The shorter the time, the more vectors of information manipulation that need to be leveraged. Likewise, the more unbiased information available in the marketplace vying for the target's attention, the more that discrediting that information becomes necessary in order to cast doubt into the minds of the target audience. The result is that propaganda and disinformation can prove to be extremely difficult to counteract once it has taken hold in the public's consciousness. Information, if conveyed well, whether factual or not, sticks in both the subconscious and conscious memories of targeted recipients and can lead to intended and unintended consequences.

Traditionally, the use of propaganda has been limited to a constrained set of vectors for information dissemination. Newspapers, radio, television, and word of mouth require the target to be present at the time the information was distributed. Conventional propaganda and disinformation required the target to "catch" the story; the connections were few and far between. As the number of sources of information accessible in daily life have increased, so too has the number of nodes at which to manipulate the overall information environment. As that environment has become increasingly polluted targets are now required to have a filtering mechanism. People are able to consume information 24 hours a day from 
a variety of information sources that often provide contradictory information. They must attempt to form reality out of a plethora of sources. Propaganda, whether white, gray, or black, and disinformation are extremely difficult to distinguish. Adding to the complexity are both conscious and unconscious facilitators of information manipulation in a global dialogue attached to many pieces of information. Most any newspaper story published online has appended a comments section, filled with hundreds and sometimes even thousands of comments, that can overwhelm or change the meaning of a story or the presentation of information. Logging in to social media networks, such as Facebook, Twitter, Instagram, or any number of others gives access to stories designed to shape the information environment.

In this contemporary information environment new tools for photo manipulation, video editing, text and voice manipulation can be, and are, used to change all aspects of information to create propaganda and disinformation. ${ }^{7}$ Tracing the use of propaganda and disinformation longitudinally from Soviet information operations in Afghanistan in the 1980s, to FSB and GRU information operations in Georgia in 2008, a detailed analysis of Russian information operations in Ukraine from 2013-2015 shows how the traditional power of propaganda and disinformation has become magnified by an increasing number of information streams, resulting in a reality distortion effect both within the targeted area and beyond. Yet at the same time it illustrates how the fundamental goals of managing the collective attitudes of a populous by the manipulation of significant symbols has endured. This manipulation allows for the creation of policy contestation both domestically and internationally where none previously existed. It takes facts and makes them fictions and preys on the conditions and foundations of how humans make decisions. The significant manipulation of information can skew cognitive biases and alter propensities for the acceptance of risk and reward.

\section{SOVIET PROPAGANDA AND DISINFORMATION IN A LIMITED VECTOR INFORMATION ENVIRONMENT: AFGHANISTAN}

By the 1980s, the massive Soviet bureaucracy had reached its apex in the formulation and implementation of propaganda abroad. Under Mikhail Gorbachev, the Soviet propaganda apparatus was reinvigorated to more readily respond to geo-political events. Each Soviet political organ involved in the production of propaganda possessed "communication" specialists with backgrounds in the methods of Western democratic society. ${ }^{8}$ Propaganda directives flowed from the Politburo across organs tasked with determining the means to achieve the specified goals abroad. The massive infrastructure utilized by the Soviets for deception during the 
1980s included press agencies, news outlets, organizations, and hundreds of journalists abroad producing articles in line with Soviet directives. ${ }^{9}$ Information vectors utilized by Soviet operatives in the Soviet-Afghan War included all the primary technologies available before the technology boom of the 1990s. But the essentially Western orientation of Soviet propaganda was a limitation in Afghanistan. In populated centers, the Soviets utilized radio and print to support their propaganda directives. The rugged geography of Afghanistan, combined with the ethnic tribalism of the Afghan agrarian populations outside the country's urban areas, decreased the effectiveness of Soviet propaganda and disinformation. As a result, the Soviets constantly confronted the challenge of propaganda permeation by resorting to a campaign of Sovietization consisting of re-education and indoctrination in areas under Moscow's control. The distinctive feature of the Soviet-Afghan information war is that the information vectors available for strategic use against the United States were largely downgraded in information operations against the Afghan populace.

(A) The Soviets utilized propaganda to achieve three primary objectives in support of combat operations in Afghanistan. First, propaganda was employed to support the Communist government of Afghanistan and to remodel Afghanistan to mirror the USSR's Muslim areas. This operation served to build proximate knowledge regarding the target population. The second objective was to degrade the operational effectiveness of the Afghan mujahideen through the use of disinformation predicated on the existing rivalries among key mujahideen leaders and their covert Pakistani and American benefactors. Soviet disinformation also attempted to exacerbate the anxieties of Pakistan's leadership in order to disrupt the covert material assistance to the mujahideen provided by the United States through its Pakistani proxies. Fragmentations in the Afghan identity both enabled and hindered the Soviet propaganda objectives. Of the estimated 17 million Afghans in 1979, Pashtuns totaled 9 million, Tajiks 4 million, Uzbeks 1.5 million, and Turkmen 1.1 million. ${ }^{10}$ Afghan diversity hindered attempts by the Soviet-backed Afghan government to extend its control to the majority Pashtun and Tajik populations, who viewed Soviet policies as an affront to Islam and therefore to their way of life. ${ }^{11}$ The Soviets nevertheless capitalized on the ethnic divisions through information operations that intensified existing rivalries among mujahideen leaders from different ethnicities. Soviet intelligence also attempted to fracture the American-Pakistani relationship by targeting a Pakistani fear of American imperialism toppling that country's undemocratic regime.

Both the KGB and the GRU had maintained a substantial covert footprint in Afghanistan prior to 1979. Despite that covert infrastructure, the KGB had somehow failed to detect the successive coups in 1978 and 1979 that ultimately provided the impetus for the Soviet invasion. Rivalries between 
the Khalq and Parcham factions truncated the Communist party of Afghanistan, the People's Democratic Party of Afghanistan (PDPA). The 1978 coup, led by Pashtun officers from the Khalq faction, took over the presidential palace and murdered Afghan President Mohammed Daoud and his family. The Communist takeover resulted in a new Communist President, Nur Muhammad Taraki. The Soviet Union embraced Taraki and supported his aggressive Marxist policies of land redistribution and the mass education of women, which created a significant backlash from the Afghan population that viewed these measures as a godless assault on Afghan social structures. ${ }^{12}$ The Afghan backlash is indicative of a limited contemporary understanding by Soviet propagandists of the social and cultural conditioning of Afghans forged over millennia in the face of repeated attempts by outside powers to impose control. The failure to account for those ingrained identity structures fostered an environment in which the Marxist measures inflamed the Islamic resistance, and the coup did nothing to extinguish existing rivalries in the Communist Party. Specifically, the rivalry between Taraki and his coup co-conspirator Hafizullah Amin posed significant problems. The KGB suspected that Amin maintained contacts with the Central Intelligence Agency (CIA), a belief attributable in large part to disinformation spread by Amin's political opponents. ${ }^{13}$ The Soviet suspicion of Amin turned to alarm when Amin overthrew Taraki's government in 1979 and ordered his execution. The worsening Islamic insurgency that threatened to spread to other Islamic areas of the Soviet Union and Amin's ascension to power created a tenuous situation that threatened Communist gains inside Afghanistan. Under Politburo direction, on 27 December 1979 the KGB conducted Operation Storm and captured the Presidential Palace. The KGB executed Amin and installed Babrak Karmal as President of Afghanistan. The KGB counter-coup occurred as the 40th Soviet army invaded Afghanistan and Soviet airborne troops seized control of Kabul. ${ }^{14}$ The next morning, a broadcast emanating from Soviet Army Headquarters, masquerading as the local Kabul radio station, announced that Karmal had assumed power. ${ }^{15}$

Soviet information operations began early and in earnest attempting to justify Moscow's interventionist policies. The Soviets then fostered a narrative centering on Amin's bloody reign of brutalization against the Afghan people and various national minorities. According to the KGB narrative, the new Karmal regime had successfully countered Amin, but not before his policies had allowed armed rebels from other countries to begin an insurrection and confusing locals with bourgeois propaganda. As a result, the Karmal government was now requesting the assistance of the Soviet Union in repelling the invaders and restoring order. ${ }^{16}$ The Soviets then went so far as to cite Article 51 of the United Nations Charter in their defense. ${ }^{17}$ The information vectors utilized by the Soviets included media, print, and 
diplomatic messaging. Despite its prevalence, this strategic messaging failed to obfuscate the Afghan internal situation or dilute the international outcry against Moscow's actions. On 7 January 1980, the Non-Aligned Group of countries sponsored a United Nations Security Council resolution condemning the Soviet operation in Afghanistan and calling for the removal of all Soviet troops from Afghan soil. ${ }^{18}$ The Soviets vetoed the resolution. The twelve Security Council members supporting the resolution responded to the Soviet veto by calling for an emergency session of the General Assembly, only the sixth in its history. The "United for Peace" emergency convention passed a resolution (104 states in favor and 18 abstaining) calling for all member states to respect Afghanistan's territorial integrity and for the immediate, unconditional withdrawal of all foreign troops from that country. ${ }^{19}$ China, emboldened by the opportunity to improve its diplomatic standing with the United States, began as early as 1980 to supply the mujahideen with covert material assistance and arms. ${ }^{20}$ President Jimmy Carter approved covert aid to, and arming of, the mujahideen in July 1979 after hearing intelligence reports of the initial Soviet troops entering Afghanistan. ${ }^{21}$ By 1982, Great Britain's MI6 began providing training, light weaponry, and communications equipment to the forces loyal to the Tajik fighter Ahmed Shah Massoud. ${ }^{22}$ Soviet strategic information operations had thus failed to obscure the nature of the invasion. By 1980, international policy directed at countering Soviet aggression began to harden.

Internally, KGB propaganda efforts focused on the Sovietization of Afghanistan and the pacification of areas resisting Soviet control. Sovietization, in this case, was the "process by which Afghanistan should be made to look like the Soviet Muslim republics." ${ }^{23}$ Sovietization targeted urban areas already under Soviet control and was separate from information operations targeting the mujahideen. Sovietization did not seek the indoctrination of ordinary Afghans into becoming Marxist ideologues. Instead, KGB propaganda focused on isolating Afghan youth from the nation's historical traditions. The continuous exposure to the Communist way of life attempted to frame traditional Afghan customs as alien. The manipulation of young Afghans was predicated on fostering an estrangement from traditional Afghan culture that would result in the adherence to Communist attitudes even in the absence of political commitment. ${ }^{24}$ To achieve this end, Karmal's Democratic Republic of Afghanistan (DRA), with the assistance of Soviet advisors, attempted to import Soviet institutions and mass organizations. The People's Democratic Party of Afghanistan (PDPA) lacked the necessary Communist intelligentsia to fully replicate the institutions of the Soviet Union. Of the PDPA's 150,000 members, 80,000 joined between 1983 and 1985. ${ }^{25}$ Membership increases were directly related to its being a prerequisite for any government position in Afghanistan. Communist cadres underwent 
irregular education sessions, but some cadres were sent to the Soviet Union for four-month-long training and indoctrination sessions. ${ }^{26}$ These educational programs resulted in minimal success in Afghanistan's urban centers. The few Afghans who became committed Communists often joined the Army in response to the encouragement they received from the PDPA and Soviet advisors. Many of these new Communists, in their socialist fervor, dedicated themselves to protecting the DRA, only to die in battle against the mujahideen.

Another challenge to successful Sovietization was overcoming the perceived intransigence of both Islam and Communism during attempts to export the religion-state relationship from Soviet Muslim republics. The envisioned religion-state relationship was designed to provide the opportunity for the observance of a politically innocuous form of Islam within a Communist system. To achieve this objective, the Politburo utilized Spiritual Administration of the Muslims of Central Asia (SADUM) in Afghanistan and throughout Asia. SADUM had served as the Islamic organization responsible for mosques and public diplomacy in Muslim areas of the Soviet Union prior to 1979. After the Afghan invasion, SADUM disseminated pro-Soviet propaganda through print, person to person, and radio. ${ }^{27}$ Propaganda directed towards Afghan Muslims highlighted the prosperity of Muslims living under Soviet rule, the existence of freedom of conscience, and the pristine conditions of mosques in the USSR. ${ }^{28}$ Increasingly, Soviet propaganda attempted to distance Communism from the violent reactionary policies of Amin that had infuriated the Afghan Islamic population and instead sought to provide a frame of reference within which Islam had nothing to fear from socialism and could in fact be compatible with it.

SADUM justified the Soviet invasion to foreign Muslim populations and denied reports of atrocities against the Afghan population. Instead, through misinformation it redirected all accusations towards American imperialism. The organization published articles in the February 1986 American-based edition of the Islamic Horizons magazine in which it denied Afghan suffering and painted the mujahideen as criminals. ${ }^{29}$ These denials ultimately estranged SADUM from the wider Muslim population of the world, who almost unanimously opposed the Soviet intervention in Afghanistan. SADUM attempted to deny the mujahideen any justification or moral basis for jihad. Leaders of the organization consistently broadcast stories on radio and through the issuance of public statements about the mujahideen detonating bombs near school-level madrasas, pursuing war against the Afghan people, and murdering Islamic clerics. ${ }^{30}$ SADUM's effort to support the DRA evolved over time. SADUM provided material assistance to DRA leaders and advised them on how to organize their religious institutions in SADUM's image. Overall, though, SADUM and 
its pro-DRA muftiate had minimal impact in convincing Afghan Muslims that Islam and Communism were compatible.

(B) Information operations in support of Sovietization relied primarily on radio and printed communication within urban centers. Communist party members utilized the Kabul News Times (KNT) as a vector to describe the party's role in the daily life of all Afghans under Soviet control. ${ }^{31}$ During the time of the PDPA's rule, 1978-1992, Afghanistan had four national daily newspapers of approximately 111,200 copies; 8 central weekly papers with a total circulation of 235,000; and 18 provincial newspapers with a total of 600,000 copies published in Pashtu and Dari. ${ }^{32}$ The low number of papers produced during the 1980s was a result of limited Afghan literacy. For that reason, the primary propaganda vehicle was Radio Kabul. The Soviet Union provided transmitters and amplifiers to ensure that radio broadcasts from Kabul could be heard nationwide, capable of reaching an estimated listening audience of between 10 to 12 million. Though radio served as the only major form of mass media in Afghanistan, it was not considered a credible source of information by the majority of Afghans during the Soviet occupation. The broadcasts were perceived as containing rampant propaganda produced by the KGB and DRA.

Information operations in support of Sovietization failed to significantly manipulate the psychological disposition of the Afghan populace at both the individual and collective levels in Soviet-controlled areas, due largely to Soviet underestimation of the social and cultural conditioning of their external and internal targets. Sovietization focused on imprinting Afghanistan with an identity based on existing societal constructs within the USSR. To alter the Afghan identity, propaganda and disinformation efforts required Afghans to eschew traditional social and culture constructs of identity, to be replaced by Soviet patterns of behavior. Persisting throughout the conflict was a traditional culture that, while not monolithic, was heavily predicated on Islamic values and education and rooted in a strong sense of history. Soviet information operations could neither effectively challenge the narrative of uncompromising Communism as an invading force, nor fully manipulate the existing social and cultural frameworks to fit within a workable Soviet mold. The PDPA's radical reforms, embarked upon in 1978, that redistributed land, shut down madrasas, and provided rights to women, among other policies pushed forward during the Soviet occupation, were seen as upending the collective identity of a patriarchal society rooted in Islamic values. The time horizon needed to overcome the traditional Afghan identity in Soviet-controlled areas necessitated that several generations be influenced by available information vectors in order that Afghan targets "catch" the Soviet narrative of Islamic-friendly socialism. That this successfully occurred across the timeframe in question cannot be confirmed. 


\section{DYNAMIC NARRATIVES AND WAR: GEORGIA, 2008}

A small conflict that erupted in 1988 between Georgia and Russia over the fate of South Ossetia intensified after the South Ossetian Autonomous Oblast of 1990 declared its independence from Georgia. ${ }^{33}$ Not only an inter-state conflict, it was an intra-state conflict between the Abkhazian and Ossetian minorities and the Georgian majority for political representation. The fall of the Soviet Union resulted in a nationalistic struggle, with Georgia attempting to maintain its new independence from Russia. Concurrently, Ossetians and Abkhazians called for the maintenance of the relative autonomy their regions had enjoyed under Soviet rule, seeking Moscow's support and protection. The resulting conflict ended with the Sochi Agreement of June 1992 which established the pre-conditions necessary for Russian intervention in the five-day war of 2008. Under the agreement, the Russian government cited South Ossetia's right to accession into the Russian Federation if human rights violations occurred in the province. During Vladimir V. Putin's first term as President, Russia's covert infrastructure increased inside both South Ossetia and Abkhazia. ${ }^{34}$ In the summer of 2008, the situation deteriorated as separatist militias began to target Georgian settlements. Georgian accusations suggested that Russia was supporting these militias with covert military assistance, while Russia in turn accused Georgia of a military mobilization that indicated imminent hostilities. The result was the outbreak of a war that ended with all Georgian troops leaving South Ossetia and Abkhazia and a significant amount of Georgia's military infrastructure destroyed.

The overall objective of the hostilities between Russia and Georgia was the determination of political control over Abkhazia and South Ossetia. While limited in scope, the Russian incursion featured a well-coordinated offensive that included the use of diplomatic pressure to complement its cyber and kinetic military operations. The Russian military's continuing domination of South Ossetia and Abkhazia provides a forward power point of projection into the South Caucuses where competing constructs of identity are especially prevalent. Russian directed multi-vectored information operations sought to reinvigorate historical hostilities.

Prior to the 2008 conflict, Moscow provided citizenship to many Abkhazians and South Ossetians in an attempt to create a "protected" Russian population as part of a larger political campaign to justify intervention in 2008. President Dmitry Medvedev, in a move similar to conflict initiation in Afghanistan, asserted that the Russian incursion was organized as a peace operation to protect Russian soldiers and civilians under attack in Georgia, again citing Article 51 of the U.N. charter. ${ }^{35}$ A narrative of Russian adherence to Article 51 muddied the identification of the initial conflict instigator. Georgia maintained that its attack against the 
city of Tskhinvali on 8 August was in response to shelling from South Ossetia into Georgia and to Russian arms shipments through the Roki tunnel into South Ossetia. In contrast to the Georgian narrative, Russian justification for intervention was rooted in the illegitimate targeting of civilian populations by Georgian armed forces. The competing narratives provided space for the more powerful Russian Federation to achieve strategic and tactical objectives before the facts could be sorted out.

Yet both narratives failed to accurately account for complex events. Visual evidence of post-Georgian artillery attacks on Tskhinvali from cell phone pictures and videos challenges Russian claims of an indiscriminate barrage against a civilian population. ${ }^{36}$ Russia's narrative also fails to account for substantial evidence suggesting the prepositioning of Russian mechanized units and their conduct of exercises on the Georgian border in the days and weeks before the war. In addition, a Russian general admitted to the presence of airborne troops in South Ossetia six days prior the start of the conflict. ${ }^{37}$ Dr. Ariel Cohen and Colonel Robert E. Hamilton have suggested a plausible scenario in which Russian-supported separatist militias escalated attacks against Georgian territory resulting in a Georgian armed response. The Russians subsequently used the Georgian response as a pretext for a pre-planned offensive to achieve geo-political goals. ${ }^{38}$

The war in Georgia was supplemented by the use offensive cyber operations (OCO), primarily in the form of distributed denial of services (DDOS) attacks against thirty-eight Georgian Websites. ${ }^{39}$ These attacks, initiated prior to the outbreak of hostilities, indicate an escalation from virtual to kinetic attacks. The OCO activities resembled non-state behaviors closely associated with significant cyber attacks against Estonia in 2007 over the removal of a Russian war memorial. The use of cyber in combination with kinetic warfare indicated a novel approach to conflict strategy, operations, and tactics. Cyber operations by Russian-affiliated forces utilized a multitude of information technologies to battle opposing narratives and produce information favorable to Russian military and political operations. Moscow, aware of the increasing prevalence and importance of the Internet by 2000 , established Websites dedicated to the dissemination of Russia propaganda. These Websites aligned in four categories. First, some represented official institutions of the Russian government. ${ }^{40}$ For example, the initial report of Georgian acts of genocide originated from Websites attributed to the Russian Prosecutor's office. Russian news Websites would then repeat and augment disinformation flows from official and unofficial sources. ${ }^{41}$ Other Websites that produced propaganda appeared as allegedly expert sites, challenging the often critical intellectual narratives of the conflict offered by academics and policy scholars. ${ }^{42}$ The Russian strategy also embraced the use of media to overwhelm the information environment with favorable news 
coverage. Moreover, Moscow embedded 50 reporters in Tskhinvali prior to the outbreak of the conflict. The Russian military conducted a few information operations with established pro-Russian media channels, but these sources were criticized inside Russia for their lack of capabilities for the effective distribution of propaganda. ${ }^{43}$ The overall influence of the Russian information operations inside Georgia was downgraded by Georgian reprisals. Georgia was able to counter Russian propaganda by jamming Russian news channels within its borders and by offering the public counter-narratives through Western news outlets.

On 10 August 2008, President Medvedev, claiming that the Georgian actions against Ossetia amounted to genocide, called for an investigation by the Russian Prosecutor's Office (Sledstvennyi Komitet Prokuratury, SKP). The use of the term "genocide" in this instance was less an accurate description of operational conditions than Moscow's mechanism to prime both domestic and international audiences with a term having extremely negative connotations. To facilitate the Russian misinformation operation, the SKP deployed 229 investigators and forensic specialists who concluded "that the goal of the aggressors was the total annihilation of the national group of Ossetians residing in South Ossetia." ${ }^{44}$ Russian newspapers augmented the political statements emanating from Moscow with stories about Georgian brutality that alleged the execution of civilians and the targeted murder of pregnant women and children to the amusement of Georgian crowds. ${ }^{45}$ Russian disinformation operations promulgated these stories of Georgian atrocities and genocide throughout Russia. Many of these fabrications were then subsequently picked up by an increasingly interconnected information environment and disseminated internationally through television, electronic Websites, and newspapers. The international organization Human Rights Watch came across many of these stories through hearsay, and despite its repeated attempts to confirm these allegations found no substantiating evidence. ${ }^{46}$ The unfounded stories of atrocities were nevertheless successful in helping to alienate the Georgian identity from minority populations in Abkhazia and Ossetia.

Prior to the start of the 2008 war, both South Ossetia and Abkhazia had maintained a small population of ethnic Georgians. Armed conflict and associated Russian information operations hardened Ossetian and Abkhazian identities and ruptured the social and cultural structures that tenuously linked the de facto republics to Georgia. Yet, the connection between Ossetian and Georgian identities had already begun to fray in the 1980 s with the reemergence of an Ossetian narrative that played on history. It had roots in the Bolshevik-Ossetian revolution of April 1920 in which Georgian forces responded to the revolt with brutal reprisals, resulting in 5,000 deaths and the displacement of 20,000-35,000 Ossetians from South Ossetia to North Ossetia. ${ }^{47}$ 


\section{Poisonous Narratives}

According to the Ossetian narrative, Georgia attempted to exterminate Ossetians during the 1988-1992 conflict, wherein Georgian nationalism viewed the autonomous region of Ossetia as a Bolshevik institution and a roadblock to Georgian territorial integrity. In 1988, the Georgian majority attempted to impose its language upon the South Ossetians, causing a widespread reaction from the Ossetians against the dominating measures. As a result, Georgians viewed the Ossetians as squatters or "ungrateful guests" who instead belonged on Russian soil in North Ossetia. ${ }^{48}$ During the conflict, militia groups emerged, fighting for respectively Georgian nationalistic aspirations of territorial integrity and Ossetian autonomy. Ethnic identities became polarized as population displacements led to specified Georgian and Ossetian zones. Under the Soviet Union, Georgian and Ossetian families had lived more or less peacefully in the same neighborhoods, but the removal of the Soviet leviathan uncorked a nationalistic fervor that resulted in a reversion to hardened identities and dismantled social structures.

The historical narrative of Abkhazia is filled with enmities towards both the Russians and Georgians. Abkhazian populations suffered massacres during Russia's imperial expansion in the 1860s, with many Abkhazians relocating to the Ottoman Empire. Throughout its Soviet history, Abkhazia maintained the status of Socialist Republic. In the face of Georgian nationalism during the 1990s, Abkhazia feared a lack of political representation and requested Russian support. By 1992, Abkhazian separatists had taken up arms against Georgian troops in a fight for independence.

Years later, as Russian forces entered Ossetia and Abkhazia in 2008, Russian information operations adopted the Ossetian narrative of genocide that existed since 1988 and co-opted it for their own geo-political goals. Russian propaganda framed the conflict as a reincarnation of the Great Patriotic War and labeled Georgian President Mikheil Saakashvili as a man intent on a genocidal campaign against the Ossetians. President Medvedev used the word "blitzkrieg" to describe the Georgian attack against Tskhinvali and the banners stating "Georgia for Georgians" as genocidal intent on the part of Tbilisi. ${ }^{49}$ Vladimir Putin visited a refugee camp in North Ossetia where he listened to stories of alleged atrocities occurring in the war. ${ }^{50}$ News agencies and Websites inside Russia parroted these stories of crimes against humanity. That narrative provoked local militias to seek reprisals against their Georgian rivals and by, the end of the war, Russian-backed irregular militias removed, plundered, and destroyed Georgian villages inside the territories of Ossetia and Abkhazia and beyond, most notably the enclave of the Greater Liakhvi gorge. ${ }^{51}$ The narrative of genocide and death toll inflations, maintained throughout the 
duration of the conflict, facilitated domestic support for Russian peacekeeping operations in Georgia. Moreover, by adopting the narrative of genocide Russia was able to claim that Georgia's actions had resulted in the forfeiture of its sovereign rights.

Russian information operations manipulated existing social cultural identities to achieve political ends. Because immediate verification of the claims was not possible, international response was modified. Russian information operations success was due to a multi-vectored misinformation strategy that leveraged minority historical social and cultural fears. KGBSVR linkage of conflicts eighty years apart biased the responses of the local populations and created a cognitive distortion that enabled the Russian operations. The genocide narrative was effective in rallying and solidifying social structures based on ethnic groups that led to a rupturing of tenuous connections between Georgia and the autonomous regions. From afar, the 2008 war can be viewed as a geo-politically motivated conflict between Georgia and Russia. But to Abkhazians and Ossetians, the conflict was the continuation of past conflicts. The deliberate distortion of events also facilitated domestic support within Russia for its intervention in the local hostilities. The short Russia-Georgia conflict was well-suited to a rapid influx of information and able to achieve substantial results without offering opponents sufficient time to adequately challenge competing narratives. The success of Russia's approach in Georgia established the mechanisms to utilize in its extended propaganda and disinformation campaigns for future operations in Ukraine and Crimea.

\section{UKRAINE-HOW TO HIDE A WAR}

Since November 2013, Ukraine and Russia have been involved in a steady conflict that has resulted in thousands of fatalities. ${ }^{52}$ Mobile devices are nearly ubiquitous in both Ukraine and Russia, and the spread of smart devices with photo and video capability is pervasive. ${ }^{53}$ Both countries have moderate access to the Internet, and by extension to global information environments. ${ }^{54}$ Ukraine has been subject to extensive Russian deception and propaganda efforts spanning traditional and modern vectors of information operations. Those operations are designed to obfuscate the invasion of sovereign territories, the skewing of voting processes and outcomes of elections, conceal the distribution and use of weapons, the number of refugees, and the composition and use of forces in theater. ${ }^{55}$ Making this conflict unique is not the use of information manipulation, but rather the implementation of propaganda and deception in a highlyconnected global information environment, and the relative degree of success these operations have had in creating a contested policy environment among European Union and North Atlantic Treaty Organization (NATO) countries. 
Unbiased public opinion polling has been routinely conducted by various international organizations and global research firms in Ukraine from the period prior to its independence in 1991 until the present. A postreferendum analysis of the vote for Ukrainian independence in 1991 provided hints at the potential cracks in the edifice of Ukraine as a unified nation-state. For instance, although the Ukraine-wide turnout for the referendum resulted in approximately 76 percent support for independence among the total electorate (individuals eligible to vote out of the total eligible voting population), removal of the oblasts or republics engaged in the present conflict or annexed (Donetsk, Luhansk, and Crimea) increases the percentage of the electorate proactively voting to support independence to 82 percent. This indicates that approximately 18-24 percent of the population in 1991 either didn't vote or voted no. ${ }^{56}$ National voter data indicated that only 10 percent of those who participated in the election voted no. But the divergence in voting patterns provides evidence of groups who were either disenfranchised or abstained from voting. Voting abstention in developing nations is often a means of protest to express a "no" and therefore should not be taken lightly.

The ethnic, religious, geographic, and economic distributions of Ukraine and Crimea have long been contentious, and provide ample grounds for disturbing information operations to take root. The International Republican Institute found, based on random sampling conducted at multiple intervals over the duration of Ukraine's independence, that as of October 201145 percent of all residents of Crimea considered themselves to be Russian and not Ukrainian. ${ }^{57}$ Interestingly, this number had diminished from 45 percent to 40 percent by $2013 .{ }^{58}$ Yet, despite these large numbers, as of May 201367 percent of the population of Crimea favored a relationship status within the construct of Ukrainian sovereignty as opposed to being part of the Russian Federation. ${ }^{59}$ This percentage represented an 8 percent increase compared to October 2011 and a 10 percent decline in Crimeans desiring separation from Ukraine and a subsequent annexation by Russia. This number, if accurate, would lead to the assumption of a far more cohesive social relationship between Crimean residents and the broader Ukrainian state.

Notably, public opinion analysis on Ukraine indicates that in the Donbas region (Donetsk and Luhansk) as late as November 2011 nearly 44 percent of respondents did not consider themselves to be Ukrainian; 25 percent considered themselves to be Russian, while an impressive 19 percent still considered themselves to be Soviet. ${ }^{60}$ The data illustrates that Ukraine, over the course of its 20 years of independence, has not yet succeeded in creating a unified identity among its people, and that large swaths of its population continue to view themselves as members of another state. 
Despite that diverse population, any support for formal action by the Russian Federation on behalf of Russian-speaking Ukrainian citizens remained, through September 2014, extremely low, with only 11 percent of all individuals in Eastern Ukraine supporting such actions, and only 11 percent of Russian-speaking Ukrainian citizens supporting Russian military intervention. ${ }^{61}$ Neither ubiquitous support nor a critical mass exists among the target population for Russian intervention, despite months of conflict. This provides an ongoing need to engage in information operations if Moscow wishes to continue manipulating the environment to achieve a more favorable position for Russian intervention, both within the specific regions and globally. In contrast to the slight support for Russian intervention among Eastern Ukrainians whose primary language is Russian, support for Russian intervention across the rest of the country is almost entirely non-existent, hovering below 6 percent in Southern Ukraine, 3 percent in Central Ukraine, and at 0 percent in Western Ukraine. ${ }^{62}$

The information environment for Russian propaganda and disinformation is extremely complex. The battle is not merely Russian versus Ukrainian. Instead, the complex and overlapping identities of resident populations are being tugged at in different ways. For the proximate Donbas region, the goal of Russian information operations is to leverage existing fragmentation in the national identities of Ukrainians and Russians into choosing the Russian identity.

The Russian Federation faces a complex information environment in which the target population has access to not only official news sources but also to the entirety of information on the Internet. Polling indicates that the Internet is now the second most widely used source for information nationwide in Ukraine, with 47 percent turning to the global information superhighway to understand political events. ${ }^{63}$ Many of the competing information narratives within the broader information environment to which the citizens of the Donbas now have access are extremely compelling. NATO has gone to unprecedented lengths to release satellite images of Russian troop movements, supply missions, and even military engagements. ${ }^{64}$ Yet, despite these overt displays of information and on the ground reports from various news agencies and the Ukrainian government, Sergei Lavrov, Russia's foreign minister, stated unequivocally to the international press that no evidence exists of Russian soldiers or weapons crossing the border. ${ }^{65}$ How then can evidence from an international organization, provided in the form of satellite images, along with reports from dozens of members of the international press and observers on the ground be juxtaposed with such a strong statement of denial? The reality is that the information environment surrounding the events in Ukraine, particularly in Eastern Ukraine, Crimea, Russia, and 
even in much of Europe, has been polluted through systematic operations designed to introduce doubt.

Shakespeare wrote of a similar sleight of hand and the use of reverse psychology. As the fictional Petruchio tames Katherina's shrewish nature, Russian information operations have so obfuscated the nature of the conflict that all but the most astute observers find it difficult to sort out fact from fiction. Since late 2013, Russia has aggressively portrayed the citizen movement \#Euromaidan (English translation) as consisting of individuals aligned with "Fascist" elements of Ukrainian society. ${ }^{66}$ But the process of taming the information environment started long before conflict erupted, and well in advance of Putin's annexation of Crimea. It began with the buildup to, and the engagement in, civil disobedience by broad and diverse swaths of Ukrainian society itself. Exploration of the numerous social media communications platforms, including Facebook, Twitter, blogs, news sites, comments, and forum posts available in the public domain, has not determined a Fascist versus non-Fascist makeup of the protests but it has facilitated an isolation of the broader phenomenon of the protests based on content analysis as either promoting or tacitly supporting them. Figure 1 illustrates the volume of content generated in Ukraine for surrounding the build-up to the eventual overthrow of Ukrainian President Viktor Yanukovych in Russian, Ukrainian, and English media within Ukraine. The content is specific to public Ukraine-based posts. The peak level of content generated in Russian, Ukrainian, and English was just under 60,000 unique posts in a single day.

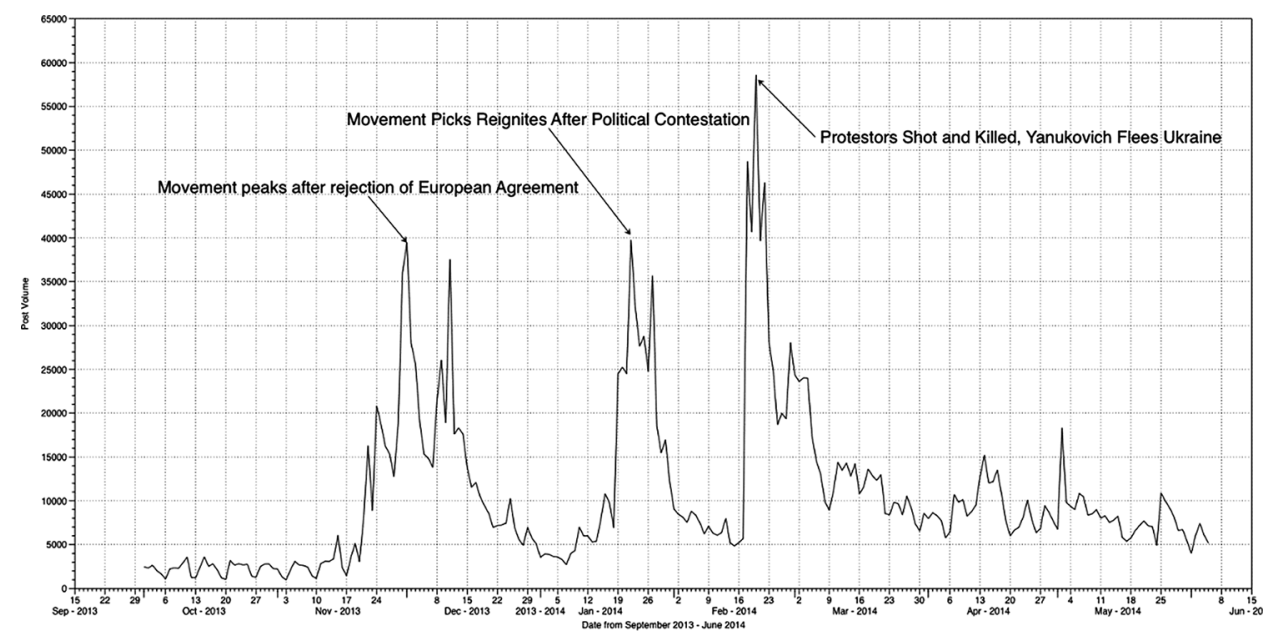

Figure 1. Post Volume During Euromaidan Protests. 
Although examples of nationalist elements were evident in the mix, the overwhelming number of conversations about the protest movements were conducted by average Ukrainians from a diverse cross-section of the country. The use of the term "fascist" is deliberate and historical. Alexander Wendt wrote "history matters," and in Ukraine, history has been the subject of political manipulation for centuries. The term fascist plays on decades of Soviet internal propaganda efforts both against the Western Ukrainian populations for their involvement with elements of the German war machine and on the conditioned history of a nation that suffered 6.8 million military and civilian dead or 16 percent of the population during World War II. By reframing the citizen movement at its earliest stages as the outgrowth of a resurgent neo-Nazi movement, the Russian Federation primed the keg to explode.

This priming is important because it relates to the issues of conditioned cultural and social frameworks and establishes a toehold for future propaganda and disinformation efforts. Irrespective of the increasingly active information environment associated with distributed information streams, the priming of a target using a conditioned cultural or social framework manipulates the target populations. Additional misinformation and propaganda fed into the information cycle further disrupts and distances individuals from non-aligned information streams. Increases in disinformation further isolate the target population from objective information frameworks, making even preposterous stories seem accurate and plausible. As hostilities between the two countries were ramping up, Russian television aired a story about "Nazi" Ukrainian soldiers torturing and crucifying a 3-year-old boy in Slovyansk in Donetsk Oblast. ${ }^{67}$ This story was remarkably similar to reports during the Russia-Georgia war of Georgian soldiers killing pregnant women before crowds of onlookers. The reports of such egregious behavior were not corroborated, nor were they retracted when shown in the international spotlight to be demonstrably false. Retractions were unnecessary because the targeted peoples were still susceptible to the information. Essentially, such a disinformation campaign takes on the behavior of "go big or go home," elevating the volume and frequency of the interjected information so that noise overwhelms an audience and provides a large volume of counter-content that is either inaccurate or misrepresented. This pool of counter-content then provides the targeted population with a wellspring of skewed information on which to build a new frame of reference. Misinformation then cascades on the targets leading them further and further away from mainstream and contradictory information sources.

When Malaysia Airlines Flight 17 was struck by a surface-to-air missile over Ukraine en route from Amsterdam to Kuala Lumpur in 2014, the 
Ukrainian intelligence service, multiple investigative reports, and the preliminary report on the accident all provided various pieces of evidence associated with the accident that included intercepted radio transmissions and satellite photos. ${ }^{68}$ The wider community also picked up on the shoot down and took screenshots of social media posts by rebel leaders claiming responsibility for the downing of the civilian aircraft. ${ }^{69}$ Yet, despite a plethora of evidence indicating rebel responsibility and Russian involvement, misinformation issued both within and beyond Russia on that country's propaganda organs such as Russia Today have consistently attempted to establish credible competing narratives. ${ }^{70}$ Russian information operations have suggested several possible competing narratives including that the plane was shot down by a Ukrainian surfaceto-air missile, that it was shot down with air-to-air cannon fire, or that it was shot down with an air-to-air missile. That last suggestion was even supported by supposed satellite imagery released more than four months after the incident. Upon inspection, the satellite imagery was found by numerous sources to have been a forgery using graphics from a video game and a model airplane with markings directly off the Boeing factory line. ${ }^{71}$ The propaganda and information flow on these incidents alone fueled animated discussions across Russia, the United States, and Europe. The articles led to confusion and obfuscation among the various publics and, while not changing U.S. or European policy positions, necessitated a response. Such responses played into a cycle of information and disinformation that further degraded the discussion on events happening in Eastern Ukraine and Crimea, as well about the actual facts surrounding the downing of a civilian airliner.

The establishment of disinformation and propaganda streams is not limited to placing falsified stories in the popular media. To confront a wave of almost universally contrary information flows emanating from Western academic institutions, think tanks, governments, and intelligence agencies, Russia began funding alternative (and sympathetic) think tank organizations and academics in Western countries to lend further credence to its developed narrative. One such "institution," the Centre for Research on Globalization, is often among the first Web search entries associated with English-language Russian propaganda and misinformation narratives. The Centre, most closely associated with University of Ottawa economics professor Michel Chossudovsky, provides cleverly crafted disinformation and propaganda. Everything about its Website and the information it distributes mimics conventional academic institutions and think-tanks. Yet its sole purpose is to offer a counter-narrative based on false, inaccurate, or misleading source material. On 31 January 2015 the site used out-ofcontext comments from a wider statement by the Chief of Staff of the Ukrainian Army, Lieutenant General Viktor Muzhenko, to insinuate that 
a counter-propaganda narrative had been floated by the West. ${ }^{72}$ The translations of text can be found as follows:

Ukrainian (Original)

На сьогоднішній день ми маємо тільки факти участі окремих військовослужвовців Звройних сил РФ, громадян РФ в складі незаконних звройних формувань у бойових діях. Бойових дій 3 підрозділами регулярної російської армії на сьогоднішній день ми теж не ведемо.

\section{Russian (Translated): ${ }^{73}$}

На сегодняшний день мы имеет некоторые факты участия отдельных военнослужащих вооруженных сил РФ, граждан РФ в составе незаконных вооруженных формирований в боевых действиях. Боевых действий с подразделениями регулярной российской армии мы также не ведем,

\section{English (Translated)}

To date, we have only the involvement of some members of the Armed Forces of the Russian Federation, as well as Russian citizens as part of illegal armed groups in the fighting. We have not seen hostilities with regular Russian army units to date.

The "research" article by the Centre for Research on Globalization quotes Gen. Muzhenko as saying: "No Russian troops are fighting against us." While his actual statement says that Russia's regular army is not in Ukraine, members of the Russian armed forces are nevertheless involved in fighting in Ukraine. The accuracy of the translation is important as it affects perceptions for policy development, particularly in regard to sanctioning efforts that seek to halt Russian involvement in the provision of both weapons and soldiers in the Eastern portions of Ukraine.

The volume of content generated from multiple sources for propaganda and misinformation campaigns is enormous. A report financed by the Institute of Modern Russia notes that the information strategy of the Russian Federation is best described as having three distinct goals: (1) to shatter communications; (2) to demoralize the enemy; and (3) to take out the opposition's command structures. ${ }^{74}$ The examples provided here are only a small portion of Russia's vast information generating enterprise whose purpose is the manipulating of individuals, and by extension communities through the creation of selective and incompatible narratives. It also seeks to manipulate and distort the international response to behaviors that under normal circumstances would result in clear and unambiguous policy cohesion among allied Western nations. 
The information environment has become so polluted and so complex that even trained observers have difficulty differentiating fact from fiction. To combat the distorted information environment in Ukraine and to set the record straight, former and current students at Kyiv's Mohyla School of Journalism and the professional Digital Future of Journalism program combined forces by creating the Website "stopfake.org." 75 The site contains a mix of content, but its administrators vow to support an unbiased and accurate portrayal of events unfolding in Ukraine. This Web-based initiative provides a domain response to propaganda and disinformation. Yet its efforts largely fall by the wayside in an already crowded Web space.

\section{SUBVERTING REALITY BY LOSING TOUCH WITH IT}

What should be evident is that the goals and objectives of classic propaganda have remained largely consistent. While the three cases examined here demonstrate differing levels of success in engaging with aggressive propaganda and disinformation campaigns during conflict situations, each also illustrates the importance that states, and in those instances the Russian Federation, place on successful manipulation of the information environment. While theories associated with propaganda and disinformation have not changed, the environment into which propaganda is disseminated has evolved. This evolution is found not merely in new technologies that permit changes to or altering of videos or images; instead the most substantial change is in the increased volume of information being disseminated, as well as the broader range of content from white propaganda to black propaganda. Because the information environment is flooded with information, individuals and their communities have greater difficulty in distinguishing accurate from inaccurate information. As a result, the objective of manipulation does not really begin with skewing the full mass of information itself, but rather in the process of "reorienting" a targeted individual or state to self-select or privilege certain information. By playing on a host of socially and culturally conditioned attributes as well as cognitive biases, a propagandist is able to feed the public's voracious appetite for information, even if that information is entirely fabricated.

If a false or misleading information stream is halted, it becomes subsumed into more transparent and accurate information sources and begins to reverse the intended manipulation. Therefore, in a digitized information environment the targets must remain focused on the world as they think it is in order to prevent the degradation and reorientation of their social or cultural foundations. Providing successful propaganda and misinformation, much like producing an enticing and engaging television show, requires 
understanding the intended audience. In hooking the audience, based either on a prior social or cultural conditioning or solely challenging their foundations for reasoned thought, the challenge is to know the targets as well or better than they know themselves. By pulling on the strings of identity that combine to make individuals and groups who they are, their orientation can be manipulated. Successful propaganda subverts reality and calls into question the foundations of knowledge. Propaganda and disinformation are more prevalent than at any other time in human history. The increasing number of channels through which potential targets receive and subsequently process information necessitates more rigorous propaganda efforts by aggressive states and greater resistance from the intended recipients. To say that the Russian Federation engages in this behavior while other states do not would be unfair. Manipulation is ubiquitous across governments, and often extends to various other organizational structures. Understanding that the objective information environment can be overcome by substantial disinformation operations indicates that the role of propaganda in 21st century intelligence cannot be minimized, and certainly not dismissed.

\section{REFERENCES}

1 Michael Nielsen, "Who Own Big Data?" MIT Technology Review, 31 January 2015, available at http://www.technologyreview.com/view/533856/who-owns-bigdata/, accessed 20 March 2015.

2 Brad Plumer, "Tweets Move Faster Than Earthquakes," The Washington Post, 25 August 2011, available at https://www.washingtonpost.com/blogs/wonkblog/ post/tweets-move-faster-than-earthquakes/2011/08/25/gIQA4iWHeJ_blog.html, accessed 31 March 2016.

3 International Telecommunication Union, The World in 2014: ICT Facts and Figures. International Telecommunication Union 2014, available at http:// www.itu.int/en/ITU-D/Statistics/Documents/facts/ICTFactsFigures2014-e.pdf, accessed 15 March 2015.

4 Carrie Kahn, "Lacking Internet, Cubans Rely On 'The Package' For Entertainment," National Public Radio (NPR), 5 January 2015, available at http://www.npr.org/blogs/parallels/2015/01/05/374986028/lacking-internet-cubansrely-on-the-package-for-entertainment, accessed 30 January 2015.

5 Sean S. Costigan and Jake Perry, Cyberspaces and Global Affairs, revised ed. (Burlington, VT: Ashgate, 2013), p. 319.

6 Loch K. Johnson, Handbook of Intelligence Studies (London and New York: Routledge, 2007), p. 58.

7 Scot Macdonald, Propaganda and Information Warfare in the Twenty-First Century: Altered Images and Deception Operations, Contemporary Security Studies (London and New York: Routledge, 2007). This book contains numerous examples of the evolution of image and video manipulation. The 
complexity and increases in skill associated with image and video manipulation have made it increasingly difficult to determine frauds.

8 Marian Kirsch Leighton, Soviet Propaganda as a Foreign Policy Tool (New York: Freedom House, 1991), p. 9.

9 Ibid., p. 33.

10 Russia (Federation), General'ny $\breve{1}$ shtab; Lester W. Grau and Michael A. Gress, The Soviet-Afghan War: How a Superpower Fought and Lost (Lawrence, KS: University Press of Kansas, 2002), p. 5. The numbers are based upon the incomplete 1979 census. As a result, population figures are approximated.

11 Antonio Giustozzi, War, Politics and Society in Afghanistan, 1978-1992 (Washington, DC: Georgetown University Press, 1999), p. 242.

12 Diego Cordovez and Selig S. Harrison, Out of Afghanistan: The Inside Story of the Soviet Withdrawal (New York: Oxford University Press, 1995), p. 31. For a historical perspective on Soviet activities in the USSR's Muslim areas, see Gregory J. Massell, The Surrogate Proletariat: Muslim Women and Revolutionary Strategies in Soviet Central Asia: 1919-1929 (Princeton, NJ: Princeton University Press, 1974)

13 Vasiliy Mitrokhin, "The KGB in Afghanistan," Odd Arne Westad and Christian F. Ostermann, eds. (Washington, D.C.: 2002), available at www.wilsoncenter.org/ sites/default/files/WP40-english.pdf, accessed 5 January 2015.

14 Panagiotis Dimitrakis, The Secret War in Afghanistan: The Soviet Union, China and the Role of Anglo-American Intelligence (London and New York: I.B. Tauris, 2013), p. 58.

15 Vasili Mitrokhin and Christopher Andrew, The World Was Going Our Way: The KGB and the Battle for Third World (New York: Basic Books, 2005), p. 402.

16 Panagiotis Dimitrakis, The Secret War in Afghanistan.

17 Ibid., p. 69.

18 Ibid., p. 90.

19 Ibid., p. 91

20 Ibid.

21 Ibid., p. xi.

22 Ibid., p. 148

23 Ibid., p. 149.

24 Olivier Roy, "The Sovietization of Afghanistan," in Afghanistan and the Soviet Union: Collision and Transformation, Milan Hauner and Robert Leroy Canfield, eds. (Ann Arbor, MI: Westview Press, 1989), p. 48.

25 Ibid., p. 53.

26 Ibid., p. 50.

27 Ibid.

28 Eren Tasar, "The Central Asian Muftiate in Occupied Afghanistan, 1979-1987," Central Asian Survey, Vol. 30, No. 2, 2011, available at http://dx.doi.org/10.1080/ 02634937.20110567068 (accessed 10 January 2015).

30 Ibid., p. 215.

30 Ibid.

31 Olivier Roy, "The Sovietization of Afghanistan," pp. 49-50. 
32 Shir Mohammad Rawan, "Modern Mass Media and Traditional Communication in Afghanistan," Political Communication, Vol. 19, No. 2, 2002, p. 160.

33 Roy Allison, "Russia Resurgent? Moscow's Campaign to 'Coerce Georgia to Peace.”' International Affairs, Vol. 84, No. 6, 2008, p. 1146.

34 Ibid., p. 1147.

35 Statement on 8 August, available at www.mid.ru

36 Ariel Cohen and Robert E. Hamilton, The Russian Military and the Georgia War: Lessons and Implications (Carlisle, PA: The Strategic Studies Institute at the U.S. Army War College, 2011), p. 77.

37 Roy Allison, "The Russian Case for Military Intervention in Georgia: International Law, Norms and Political Calculation," European Security 18, no. 2, 2009, p. 176. 38 Ariel Cohen and Robert E. Hamilton, The Russian Military and the Georgia War. 39 Ibid., p. 44.

40 Aleksandr Belousov, "Political Propaganda in Contemporary Russia," Russian Politics and Law, Vol. 50, No. 3, 2012. Examples include: Kremlin.ru and Edinros.ru

41 Ibid. Examples include: Strana.ru; Vz.ru. Rian.ru; Regnum.ru.

42 Ibid. Examples include: Russ.ru; Kremlin.org; Liberty.ru; Mediacratia.ru.

43 Carolina Vendil Pallin and Frank Westerlund, "Russia's War in Georgia: Lessons and Consequences," Small Wars \& Insurgencies, Vol. 20, No. 2, 2009, p. 404.

44 Human Rights Watch, Up in Flames: Humanitarian Law Violations and Civilian Victims in the Conflict over South Ossetia (New York, 2009), p. 70.

45 Ibid., p. 71.

46 Ibid.

47 Gerard Toal and John O’Loughlin, "Inside South Ossetia: A Survey of Attitudes in a De Facto State," Post-Soviet Affairs, Vol. 29, No. 2, 2013, p. 140.

48 Thornike Gordadze, 'Georgia' and Its 'Ungrateful Guests,' Critique Internationale, No. 10, 2001.

49 Gerard Toal and John O'Loughlin, "Inside South Ossetia: A Survey of Attitudes in a De Facto State," p. 143.

50 Tamara Nosenko, "Propaganda War," Vienna Review, available at www.viennareview.net/news/special-report/propaganda-war, accessed 20 January 2015.

51 Ellen Barry, "Report Faults All Parties in War in Georgia," The New York Times, 18 November 2008, available at www.nytimes.com/2008/11/18/world/europe/ 18 georgia.html?r=0, accessed 17 January 2015.

52 "Death Toll in Ukraine Conflict Exceeds 5,000, May Be 'Considerably Higher' UN," United Nations News Centre, 23 January 2014, available at http://www.un. org/apps/news/story.asp?NewsID=49882\#.VMp788a4kUE

53 International Telecommunication Union, Mobile-Cellular Telephone Subscriptions, 2014, available at http://www.itu.int/en/ITU-D/Statistics/Documents/statistics/2014/ Mobile_cellular_2000-2013.xls

54 International Telecommunication Union, Percentage of Individuals Using the Internet, 2014, available at http://www.itu.int/en/ITU-D/Statistics/Documents/ statistics/2014/Individuals_Internet_2000-2013.xls 
55 Peter Pomerantsev, "The Menace of Unreality: How the Kremlin Weaponizes Information, Culture and Money." New York, 2014, available at http://imrussia. org/media/pdf/Research/Michael_Weiss_and_Peter_Pomerantsev_The_Menace_of_ Unreality.pdf

56 Chrystyna Lalpychak, "Over 90 Vote Yes in Referendum; Kravchuk Elected President of Ukraine," The Ukrainian Weekly, 1 September 1991; Andrew Wilson, Ukrainian Nationalism in the 1990s: A Minority Faith (Cambridge and New York: Cambridge University Press, 1996).

57 International Republican Institute, Public Opinion Survey, Residents of the Autonomous Republic of Crimea September 20-October 2, (Washington, D.C.: 2011), available at http://www.iri.org/sites/default/files/2011 November 21 Survey of Crimean Public Opinion, September 20-October 2, 2011.pdf

International Republican Institute, Public Opinion Survey Residents of the Autonomous Republic of Crimea May 16-30, (Washington, D.C., 2013), available at http://www.iri.org/sites/default/files/2013 October 7 Survey of

59 Crimean Public Opinion\%2C May 16-30\%2C 2013.pdf

Ibid.

60 International Republican Institute, Public Opinion Survey, Residents of Ukraine October 30-November 11, (Washington, D.C., 2011), available at http://www.iri. org/sites/default/files/2012 January 26 Survey of Ukrainian Public Opinion\%2C October 30-November 11\%2C 2011.pdf

61 International Republican Institute, Public Opinion Survey, Residents of Ukraine September 12-25. (Washington, D.C., 2014), available at http://www.iri.org/ sites/default/files/2014 October 14 Survey of Residents of Ukraine $\% 2 \mathrm{C}$ September 12-25\%2C 2014.pdf

62 Ibid. Notably, the poll excludes Crimea.

63 International Republican Institute, Public Opinion Survey, Residents of Ukraine September 12-25.

64 "New Satellite Imagery Exposes Russian Combat Troops Inside Ukraine," 2014, available at http://aco.nato.int/new-satellite-imagery-exposes-russian-combattroops-inside-ukraine.aspx

65 "Russia Has 9,000 Troops in Ukraine-President Poroshenko," BBC News, 21 January 2015, available at http://www.bbc.com/news/world-europe-30913027. See also, Agnia Grigas, Beyond Crimea: The New Russian Empire (New Haven, CT: Yale University Press, 2016), p. 54.

66 Joshua Keating, "Fascists, Fascists, Everywhere," Slate, 20 February 2014, available at http://www.slate.com/blogs/the_world_/2014/02/20/russia_says_the_ ukrainian_protesters_are_fascists_and_nazis_are_they.html

67 "State-Run News Station Accused of Making up Child Crucifixion," The Moscow Times, 14 July 2014.

68 Doug Stanglin, "Ukraine: Intercepted Calls Pin MH17 Shootdown on Rebels," USA Today, 18 July 2014; Preliminary Report: Crash Involving Malaysia Airlines Boeing 777-200 Flight MH17. The Hague, n.d., available at http:// www.onderzoeksraad.n1/uploads/phase-docs/701/b3923acad0ceprem-rapport-mh17-en-interactief.pdf; Iggy Ostanin, "Military \& Defense More: Russia Ukraine 
MH17 Missile the Most Damning Evidence Yet That Russia Is Responsible For the MH17 Tragedy," Business Insider, 8 September 2014.

Ishaan Tharoor, "The Evidence That May Prove Pro-Russian Separatists Shot Down MH17," The Washington Post, 20 July 2014, available at http://www. washingtonpost.com/blogs/worldviews/wp/2014/07/20/the-evidence-that-mayprove-pro-russian-separatists-shot-down-mh17/

70 "US Dismisses Russian MH17 Pictures That Blame Ukraine for Disaster," The Guardian, 15 November 2014, available at http://www.theguardian.com/world/ 2014/nov/15/ukraine-fighter-shot-mh17-claims-russian-tv-photo-fake; "Russia to Probe Media Reports That Ukraine Military Shot down MH17," Russia Today, 23 December 2014, available at http://rt.com/news/216871-ukrainemilitary-mh17-report/; "MH-17: The Untold Story," Russia Today, 2014, available at http://rt.com/shows/documentary/197540-mh-17-crash-ukraine/

71 Aric Toler, "Kremlin Has Mastered Propaganda, But Not Photoshop: Fake MH17 Photo Lights Up RuNet," Global Voices Online, 2014, available at http:// globalvoicesonline.org/2014/11/15/russia-photoshop-kremlin-mh17-ukraine-crash/; Associated Press, "Russian TV Claims It Has Photo of Downing of MH17," The New York Times, 15 November 2014, available at http://www.nytimes.com/ aponline/2014/11/15/world/europe/ap-eu-russia-ukraine-malaysian-plane.html

72 Eric Zuesse, "Ukrainian Government: 'No Russian Troops Are Fighting Against Us'. Sanctions against Russia Based on Falsehoods," Centre for Research on Globalization, 31 January 2015.

73 “Муженко: Украина Не Воюет С Регулярными частями Армии РФ." РиА Новости Украuна, 29 January 2015, available at http://rian.com.ua/society/ 20150129/362743379.html

74 Peter Pomerantsev and Michael Weiss, "The Menace of Unreality: How the Kremlin Weaponizes Information, Culture and Money," 2014, available at http://www.interpretermag.com/wp-content/uploads/2014/11/The_Menace_ of_Unreality_Final.pdf?utm_content=buffer6022e\&utm_medium=social\&utm_ source=twitter.com\&utm_campaign=buffer, p. 14 .

75 "StopFake.org," 2014, available at http://www.stopfake.org/en/news 